\section{A Large Controversy from a Small Town: Johann Georg von Soldner of Feuchtwangen}

\section{Bismark Singh}

Does your hometown have any mathematical tourist attractions such as statues, plaques, graves, the café where the famous conjecture was made, the desk where the famous initials are scratched, birthplaces, bouses, or memorials? Have you encountered a mathematical sight on your travels? If so, we invite you to submit an essay to this column. Be sure to include a picture, a description of its mathematical significance, and either a map or directions so that others may follow in your tracks.

> Submissions should be uploaded to http://tmin.edmgr.com or sent directly to Ma. Louise Antonette N. De Las Peñas, mathtouristl@gmail.com.
$\mathrm{G}$ eorgenhof is an almost unknown village that borders the small Bavarian town of Feuchtwangen. This village has the distinction of being the birthplace of Johann Georg von Soldner, a man of diverse scientific talents in mathematics, astronomy, physics, and geodesy.

A long list of honors, including national awards and streets bearing his name in various German cities, recognize Soldner's achievements (see, e.g., [3, 22]). Feuchtwangen is no exception, and it honors Soldner as its hero. The town's Fränkisches Museum displays a commemorative plaque with a short description of Soldner (Figure 1). The regional newspaper Fränkische Landeszeitung recently honored Soldner with the short piece "Bedeutender Sohn Feuchtwangens" (Feuchtwangen's Distinguished Son) [14]. A street in the town, Von-Soldner-Straße, bears his name as well (Figure 2).

The easiest way to get to Georgenhof is by crossing the small railroad bridge that separates the village from Feuchtwangen; Ansbach and Nuremberg are probably the best-known cities near Feuchtwangen. Immediately after the railroad crossing, one sees a couple of old houses. That is all there is in Georgenhof. The second of these is the birthplace of von Soldner (Figure 3a). A black memorial plaque with gold letters installed in 1912 showers praise on von Soldner (Figure 3b). The text can be approximately translated thus:

Johann Georg von Soldner Councilor of the Royal Cadastral Commission, Astronomer of the Royal Court, and Executive Officer of the observatory in Munich, ordinary member of the Bavarian Academy of Sciences. Saw the light of day in this house on July 16,1776

The Association of Senior Bavarian Surveyors dedicates this plaque to the grateful memory of the immortal contributions of the great geodesist to the Bavarian land survey.

1912.

Bavaria was surveyed between 1808 and 1853, and large-scale cartographic maps were developed for the first time $[2,11]$. Soldner was persuaded to join the commission carrying out these surveys in the capacity of a mathematical (trigonometric) geodetic expert, and he quickly rose in the ranks. He received the above-mentioned honors in succession: councilor of the Bavarian Royal Tax Survey Commission (1811), full member of the Bavarian Academy of Sciences (1813), Royal Astronomer (1815), and director of the Munich Observatory (1816) (see, e.g., [1, 11, 22]). To appreciate these contributions, we need to look back a few decades. 


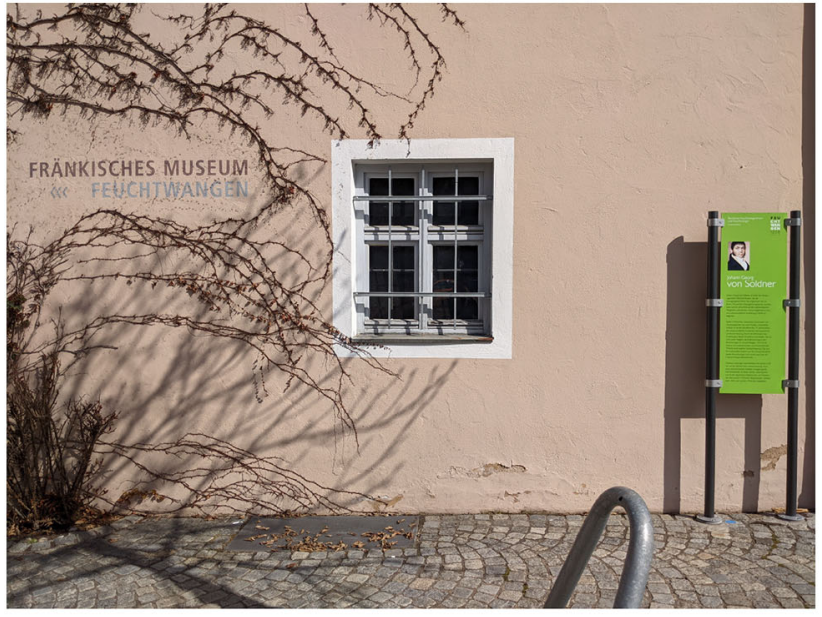

(a)

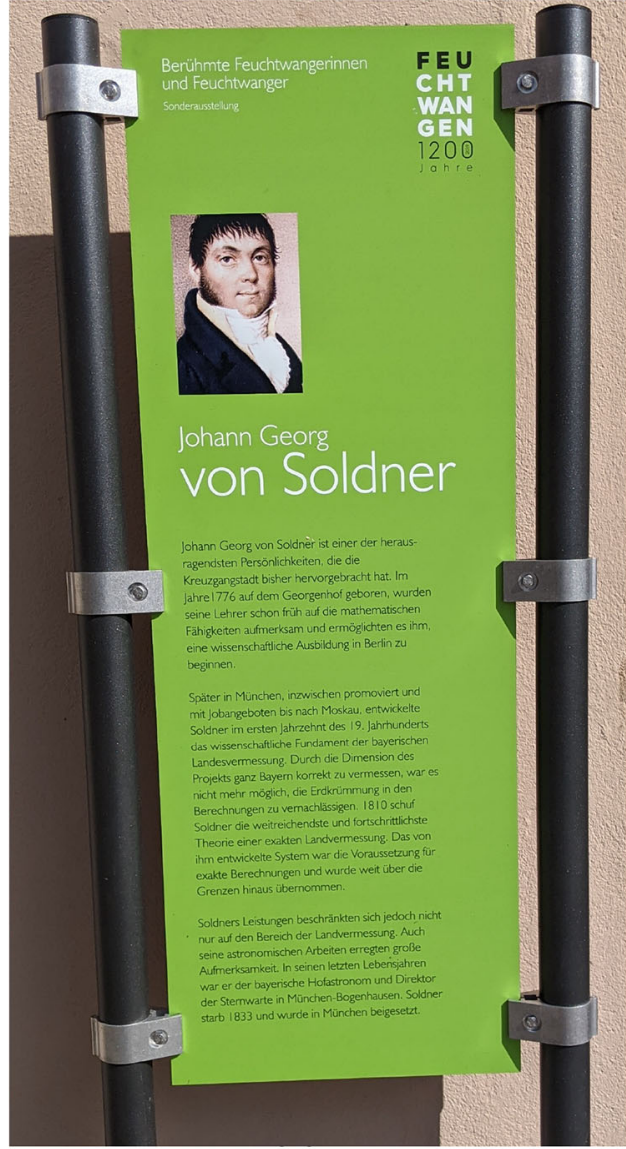

(b)

Figure I. (a) The Fränkisches Museum in Feuchtwangen with its commemorative plaque (b) honoring Soldner. Photographs by the author.

In 1744, the French cartographer César-François Cassini began working on a map that employed geodetic triangulation (see, e.g., [9, 13]), probably the first application of plane coordinate geometry in cartography. Although the work had some shortcomings, the idea behind it was revolutionary at the time, and French cartographic maps became the universal benchmark [13]. Soldner, however, discontinued the use of this plane coordinate system, instead improving on the existing standard by employing rectangular and spherical coordinates for the first time. The Cassini-Soldner projection method is still available in major mapping software such as ArcGIS and PROJ.

Soldner's scientific life before his geodetic contributions in Munich seemed to go largely unnoticed, even by academicians close to his area of research. In 1801, Soldner wrote an article that has now gained much scientific as well as political controversy. He proposed that like other materials, light is subject to gravity - a seemingly harmless scientific topic. ${ }^{1}$ In 1978, Stanley Jaki translated Soldner's article in full from German to English with the title "On the Deviation of a Light Ray from Its Motion along a Straight Line through the Attraction of a Celestial Body Which It Passes Close By" [10]. Jaki also provided an extensive historical context for Soldner's article and was remarkably candid in pointing out the irony of academicians "forgetting" Soldner's work. Jaki further pointed out that Soldner's discovery was largely overlooked even by Soldner's biographers and in a later dissertation on his academic life [10, footnote 3]. To appreciate the controversies surrounding this work-from over two hundred years ago—we need to

\footnotetext{
${ }^{1}$ It seems that Soldner wrote this article in 1801, but the Astronomisches Jahrbuch published it only in 1804. References [10] and [17] do not explain this discrepancy and I do not have a convincing resolution of it.
} 


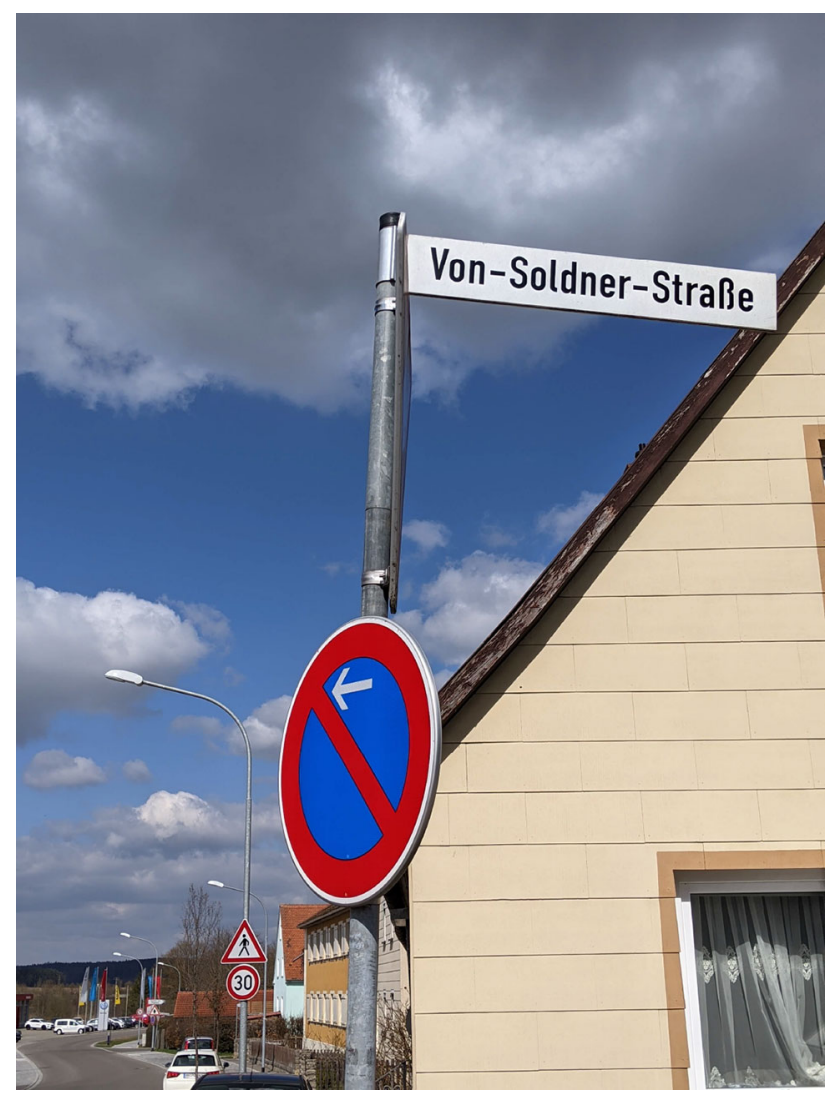

Figure 2. Von Soldner Street in Feuchtwangen. Approximate coordinates: $49^{\circ} 10^{\prime} 17.8^{\prime \prime} \mathrm{N} 10^{\circ} 19^{\prime} 41.9^{\prime \prime} \mathrm{E}$. Photograph by the author.

look forward over a hundred years after Soldner's publication.

In 1907, Albert Einstein concluded that the effect of gravity on the bending of light near celestial bodies existed but that it was too small to measure and verify. In 1911, he quantified this value for light rays around the Sun to $0.83^{\prime \prime}$. In 1916, he recalculated the value, almost doubling it to $1.7^{\prime \prime}$. Soldner had calculated this same value as $0.84^{\prime \prime}$ in 1801, but Einstein made no reference to Soldner's work. In
1919, Frank W. Dyson presented results from an experimental expedition that had been launched a few years earlier that confirmed Einstein's predicted value. In 1922, Einstein was awarded the Nobel Prize in Physics for his contributions to theoretical physics and especially for his discovery of the law of the photoelectric effect, but not for his work on relativity.

In 1921, Philipp Lenard, who won the 1905 Nobel Prize in Physics for work on cathode rays, brought attention to Soldner's work by reproducing it for the first time [17]. ${ }^{2}$ Lenard's intent in reviving this forgotten work was questionable, given the political situation in Germany at the time. Lenard was a supporter of Hitler, an antirelativist, and an anti-Semite. The importance of reviving Soldner's work was clear: Soldner used Newtonian physics, while Einstein's "Jewish" work proposed a profoundly updated set of rules for the universe. In 1923, Lenard and two others formally accused Einstein of plagiarizing Soldner's 1801 result. Einstein, however, had also attacked Lenard by dismissing the latter's claims in 1920 [6, pp. 105-106].

Jean-Marc Ginoux gave detailed comparisons of the two works by several scientists in addition to providing a historical timeline [8]. He also quoted a statement that had appeared in the New York Times on April 13, 1923, by Captain Thomas Jefferson Jackson See, an American astronomer at the former U.S. Naval Observatory at Mare Island. ${ }^{3}$ The New York Times actively covered these developments around the year 1923. The frequency of the letters to the editor on this subject further highlights the interest aroused by this controversy, even for the general public, across the Atlantic [4, 7]. See's accusation concluded that the source of the error in Soldner's 1801 work is exactly the same as that in Einstein's 1911 work [8]. Lenard pointed out the errors and corrected them in his reproduction [20]; see also [18] for a further discussion of these errors.

Several questions remained, and they remain fiercely contested to this day. Had Einstein been aware of Soldner's result? Was Soldner's value a typographical error? Were Lenard's accusations, and support for Soldner's work, sidelined because of his pro-Nazi views? In the last few decades, historians of science and mathematics have continued the debate. ${ }^{4}$ Indeed, some of the debates far

\footnotetext{
${ }^{2}$ For an overview of Lenard's career, see [12].

${ }^{3}$ Ginoux does not mention See in his article [8], but the Times of April 21, 1923, provided a more detailed account of See's plagiarism charges against Einstein [19]. For a biography of See's illustrious scientific life and the associated controversies, see [15].

${ }^{4}$ See the references in $[8,10,21]$.
} 


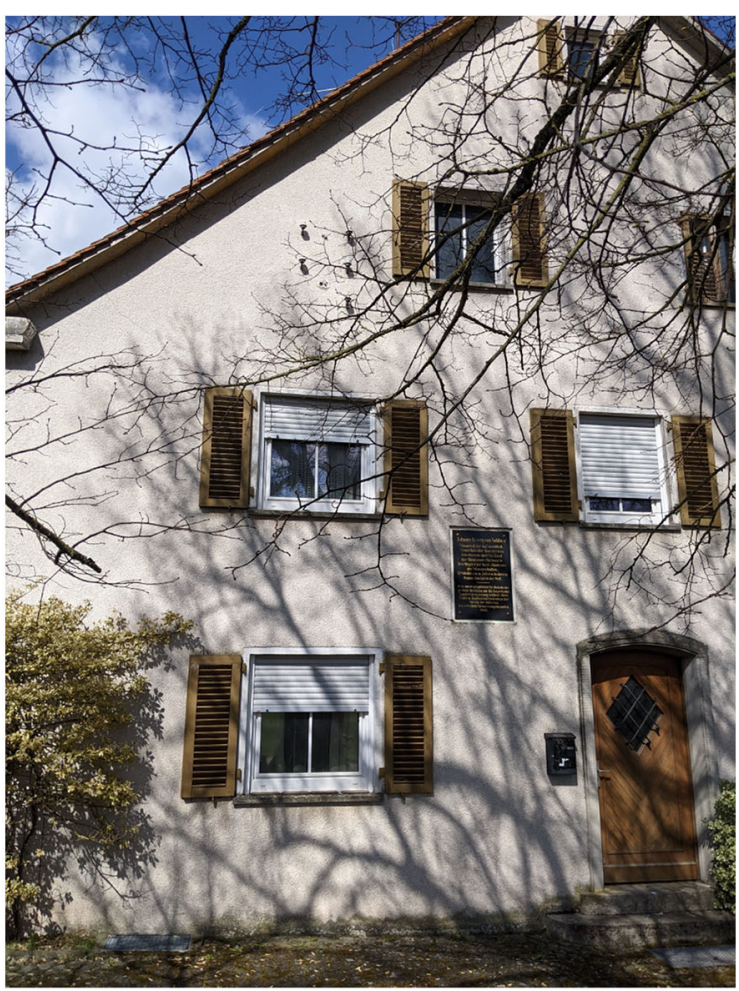

(a)

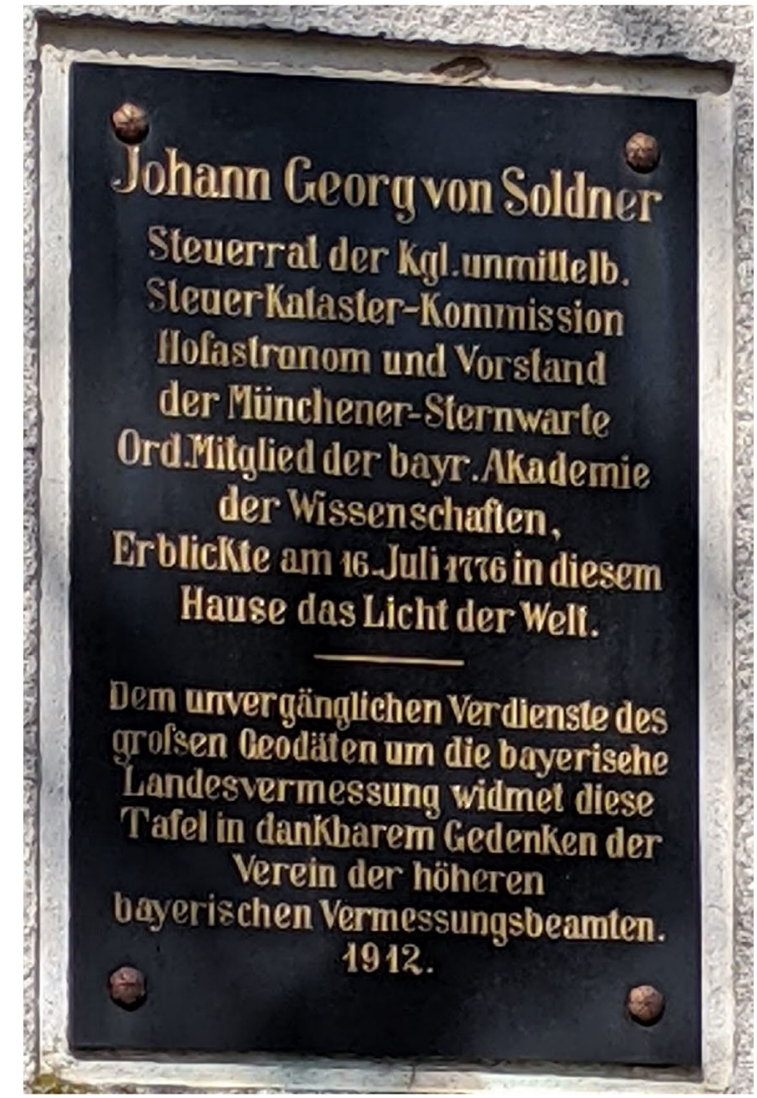

(b)

Figure 3. (a) Birthplace of von Soldner near Feuchtwangen, Germany. Approximate coordinates: $49^{\circ} 10^{\prime} 56.2^{\prime \prime} \mathrm{N} 10^{\circ} 19^{\prime} 10.4^{\prime \prime} \mathrm{E}$. (b) Closeup of the the memorial plaque on the side of the house. See the translation in the main text. Photographs by the author.

preceded Einstein's birth. Sometime between 1783 and 1804, Henry Cavendish researched and published an estimate of the contentious value that is close to that given by Soldner [5, 21]. Fundamental scientific discoveries are often marred by politics. In this example, the controversies ironically helped the scientific community by reviving forgotten works of these two great minds. After the Nazi era, U.S.-Soviet politics continued such scientific-political debates. $^{5}$

There will likely never be a universally convincing answer to the question of Soldner's influence on Einstein. Modern accounts of Einstein's work are careful not to become embroiled in debate and nearly always also point to Soldner's earlier work. But that does not preclude us from asking this rhetorical question: would Soldner's works have been revived had it not been for these polemics? What remains uncontested, and outside the realm of politics, is that Soldner achieved nearly accurate results and made seminal contributions to science and mathematics. We suggest visiting Feuchtwangen and its monuments and feeling in the air the attention, fame, and controversy that are now forever tied to this small and beautiful town.

\section{ACKNOWLEDGMENTS}

I thank Wolfgang Volk for his assistance in a few explanations and the translation of Figure 3. I thank Katja Holzner for pointing out reference [14]. Any errors are my responsibility.

\section{FUNDING}

Open Access funding enabled and organized by Projekt DEAL.

\section{OPEN ACCESS}

This article is licensed under a Creative Commons Attribution 4.0 International License, which permits use, sharing, adaptation, distribution and reproduction in any medium or format, as long as you give appropriate credit to the original author(s) and the source, provide a link to the Creative Commons licence, and indicate if changes were made. The images or other third party material in this article are included in the article's Creative Commons licence, unless indicated otherwise in a credit line to the material. If material is not included in the article's Creative Commons

${ }^{5}$ See [16] for a few examples. 
licence and your intended use is not permitted by statutory regulation or exceeds the permitted use, you will need to obtain permission directly from the copyright holder. To view a copy of this licence, visit http://creativecommons. org/licenses/by/4.0/.

Bismark Singh

Departments of Mathematics and Data Science

Friedrich-Alexander-Universität Erlangen-Nürnberg

91058 Erlangen

Germany

e-mail: bismark.singh@fau.de

\section{REFERENCES}

[1] Carl Max von Bauernfeind. Johann Georg von Soldner und sein System der Bayerischen Landesvermessung. Technische Informationsbibliothek (TIB), Munich, 1885.

[2] Bavarian State Library Online. Cartographic maps of the 19th century, March 2021. Available at https://www.bayerische-land esbibliothek-online.de/enortsblaetter.

[3] Martin Beblo. Soldner, Johann Georg von (bayerischer Personaladel 1825), volume 24, pp. 547-549. Neue Deutsche Biographie, 2010.

[4] Frederick Drew Bond. Relating to relativity. New York Times, May 13, 1923. Available at http://timesmachine.nytimes.com/time smachine/1923/05/13/105862377.html.

[5] Henry Cavendish. The Scientific Papers of the Honourable Henry Cavendish, F. R. S., volume II. Cambridge, 2011.

[6] John Cornwell. Hitler's Scientists: Science, War, and the Devil's Pact. Penguin, 2004.

[7] F. D. D. Letter to the editor. New York Times, May 13, 1923. Available at http://timesmachine.nytimes.com/timesmachine/ 1923/05/13/105862382.html.

[8] Jean-Marc Ginoux. Albert Einstein and the doubling of the deflection of light. Foundations of Science February 2021, 1-22. https://doi.org/10.1007/s10699-021-09783-4.

[9] Anne Marie Claire Godlewska. Geography Unbound; French Geographic Science from Cassini to Humboldt. University of
Chicago Press, 1999. https://doi.org/10.7208/chicago/ 9780226300535.001 .0001$.

[10] Stanley L. Jaki. Johann Georg von Soldner and the gravitational bending of light, with an English translation of his essay on it published in 1801. Foundations of Physics 8:11-12 (1978), 927950. https://doi.org/10.1007/bf00715064.

[11] M. Kneissl. Munich, a center of geodesy in Germany. Bulletin géodésique, 55:1 (1960), 5-18. https://doi.org/10.1007/ bf02539492.

[12] Joseph F Mulligan. Heinrich Hertz and Philipp Lenard: two distinguished physicists, two disparate men. Physics in Perspective 1:4 (1999), 345-366. https://doi.org/10.1007/s000160050027.

[13] Erwin Raisz. Time charts of historical cartography. Imago Mundi 2:1 (1937), 9-16. https://doi.org/10.1080/03085693708591829.

[14] Peter Sennfelder. Bedeutender Sohn Feuchtwangens. Fränkische Landeszeitung, April 2021.

[15] Thomas J. Sherrill. A career of controversy: The anomaly of T. J. J. See. Journal for the History of Astronomy 30:1 (1999), 25-50. https://doi.org/10.1177/002182869903000102.

[16] Bismark Singh. Popov, Berg, Sokolov: a street with three plaques. Mathematical Intelligencer 41:4 (2019), 13-15. https://doi.org/10. 1007/s00283-019-09936-1.

[17] J. Soldner. Über die Ablenkung eines Lichtstrahls von seiner geradlinigen Bewegung durch die Attraktion eines Weltkörpers, an welchem er nahe vorbeigeht. Annalen der Physik 370:15 (1921), 593-604. https://doi.org/10.1002/andp.19213701503.

[18] Tilman Sauer. Soldner, Einstein, gravitational light deflection and factors of two. Annalen der Physik 533, 2100203, 2021.

[19] Time. Science: Einstein and See, April 1923. Available at http:// content.time.com/time/subscriber/article/0,33009,845916-1,00. html.

[20] H.-J. Treder and G. Jackisch. On Soldner's value of Newtonian deflection of light. Astronomische Nachrichten 30:6 (1981), 275278. https://doi.org/10.1002/asna.2103020603.

[21] David Valls-Gabaud. The conceptual origins of gravitational lensing. In AIP Conference Proceedings. AIP, 2006. https://doi. org/10.1063/1.2399715.

[22] Wolfgang Volk. Johann Georg Soldner (1776-1833), April 2020. Available at http://www.math.berlin/mathematiker/johann-georgsoldner.html.

Publisher's Note Springer Nature remains neutral with regard to jurisdictional claims in published maps and institutional affiliations. 